\title{
The Dramatic Difference Between Epictetus and other Stoics in the Frequency of Use of the Terms "Hegemonic" and "Proairesis"
}

\author{
By Franco Scalenghe*
}

\begin{abstract}
The comparative analysis of the frequency of use of the term "proairesis" with respect to the term "hegemonic" in the "Stoicorum Veterum Fragmenta," the "Meditations" of Marcus Aurelius and the "Discourses and Manual" of Epictetus, shows a striking discrepancy between the choice of Epictetus and that of the other Stoics. The results of the present research favor the conclusion that such dramatic difference has an exquisitely philosophical root. This root can be traced back to the highly original and convincing arguments provided by Epictetus and that allow us to define the human being as a creature equipped by nature not only with a "hegemonic," as all other living creatures are; but equipped by nature with the "proairesis," that is with the special faculty of the hegemonic that characterizes human nature thanks to its ability to recognize the nature of things.
\end{abstract}

\section{Introduction}

The present paper is dedicated to a synopsis of all the occurrences of the term "hegemonic" in Epictetus, as well as to a synthetic summary of the total occurrences of the terms "proairesis," "proairetic," "aproairetic" and "hegemonic" in the "Stoicorum Veterum Fragmenta" (from now on referred to as "SVF") and in the "Meditations" of Marcus Aurelius. To this regard I want to make it clear that all the present quotations of the works of Epictetus as edited by William Abbot Oldfather are taken from my new complete and unabridged English translation from the ancient Greek of all Epictetus. ${ }^{1}$ Moreover, in this paper all my quotations of the "Memoirs" of Marcus Aurelius as edited by Joachim Dalfen ${ }^{2}$ and of the "SVF" as edited by Hans von Arnim ${ }^{3}$ are taken from my new, complete and unabridged Italian translation from the ancient Greek of both these texts. The most distinctive feature of all these new translations is the fact that

* Independent Scholar, Former member of the Laboratorio Internazionale di Genetica e Biofisica (LIGB) of the CNR (National Research Council), Italy.

1. William Abbot Oldfather, Epictetus: "The Discourses as reported by Arrian, the Manual and the Fragments" (London: Heinemann, 1961). My new unpublished translation is availabte at www.epitteto.com.

2. Joachim Dalfen, Marci Aurelii Antonini "Ad se ipsum Libri XII" (The Emperor Marcus Aurelius Antoninus "To himself, Books 12") (Leipzig: Teubner, 1979). My new unpublished translation is availabte at www.epitteto.com.

3. Hans von Arnim, "Stoicorum Veterum Fragmenta" (Ancient Stoic Fragments) (Leipzig: Teubner, 1905). My new unpublished translation is availabte at www.epitteto.com. 
they are strictly based upon the careful analysis of the corresponding "Index Verborum" included in their critical editions. Taking advantage of these Indexes, I have tried, in the first place, to be scrupulous in giving to each Greek word (noun, adjective or verbal form, etc.) one or the least possible number of meanings consistent with the different contexts in which they appear, and then to keep the number of their occurrences in my English or Italian translations consistent with the number of occurrences of the word in the Greek texts. I believe that this attempt, to my surprise and also, I must say, satisfaction, has been basically successful.

\section{The Stoics and the Term "Hegemonic"}

It is well known that the Stoics abandoned previous theories about the multiple partitions of the human soul, and established that it consists of eight parts. According to them, seven parts (the organs devoted to sight, hearing, touch, taste, smell, speech and reproduction) are used as sensors for the eighth

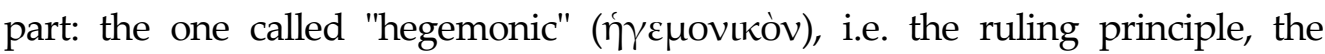
central governing entity that collects the messages coming from the first seven parts, integrates, elaborates, and sends them back to the different parts of the body. Thus according to Aetius: "The Stoics say that the hegemonic is the highest part of our soul; the part that gives rise to imaginations ( $\varphi \alpha \nu \tau \alpha \sigma i \alpha \mathrm{t})$, to assents

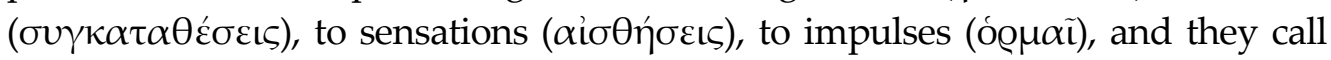
this part reasoning power. The seven parts of the soul pop out from the hegemonic and spread out to the body like the tentacles of the octopus. Five of these seven parts are sense organs: sight, smell, hearing, taste and touch. Of them, the sight is a current of pneuma which extends from the hegemonic to the eyes; hearing is a current of pneuma which extends from the hegemonic to the ears; the sense of smell is a current of pneuma which extends from the hegemonic to the nostrils; the taste is a current of pneuma which extends from the hegemonic to the tongue; the touch is a current of pneuma which extends from the hegemonic to the tactile surface that senses the bodies. Of the remaining parts, one is called "semen;" and is also a current of pneuma which extends from the hegemonic to the sexual organs. The part that Zeno calls "vocal" and that they also call "voice," is a current of pneuma which extends from the hegemonic to the pharynx, tongue and the vocal organs." And Chrysippus, in turn, says: "As the spider in the middle of the web holds with its legs all the ends of the wires, and is able to immediately feel every bump of animals whatever be their origin; so the hegemonic of the soul perceives the first hints of activity of the senses and is immediately warned about what is going on. ." $^{\text {" }}$

\footnotetext{
4. Aetius, "Stoicorum Veterum Fragmenta" (Book II, Fragment 836).

5. Calcidius, "Stoicorum Veterum Fragmenta" (Book II, Fragment 879).
} 


\section{The "Hegemonic" is a Very Busy Place}

The fact that the hegemonic deals with an enormous mass of information obviously implies its great complexity, as is shown by these words of Iamblichus quoted by Stobaeus: "The followers of Zeno share his opinion that the soul is made up of eight parts and, as to the components that it contains, that they are many. For example the hegemonic contains imaginations, assents, impulses and

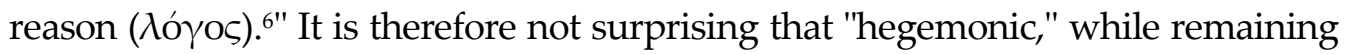
the canonical term used to indicate the ruling principle of the soul, through a synecdoche could also be called by different Stoics and for specific purposes, with the name of one of the several components in which it materialized itself. In the Stoic texts, some of the more frequent of these designations are the following: a)

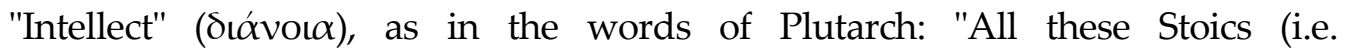
Menedemus, Ariston of Chios, Zeno and Chrysippus) legitimize the idea that the passionate and irrational part of the soul is not distinct from its rational part due to a difference of nature, but that it is the same part of the soul, precisely the one called "intellect" or "hegemonic," which is able to turn itself around and change completely its attitude if it happens to be prey to strong influences, becoming vice

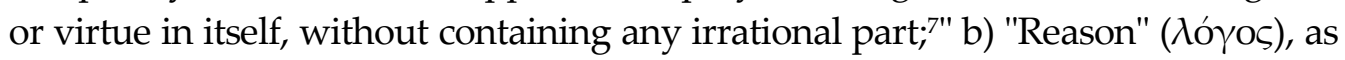
in the words of Diogenes Laertius: "The hegemonic is the dominant part of the soul, the one in which imaginations and impulses arise, and from which issues reason; ;" c) "Sensation" ( $\alpha$ ǐ $\sigma \theta \eta \sigma \iota \varsigma)$, as in the words of Aetius: "The Stoics say that when the human being is born, the hegemonic part of his soul is like a sheet of paper ready for handwriting and on which the concepts are written one by one. The first way to write on this paper is through the sensations. Those who have the sensation, for example, of something white, after the disappearance of the object have the memory of it. And when we have many correlated memories of an object, then we claim to have knowledge of it; because to be expert of something

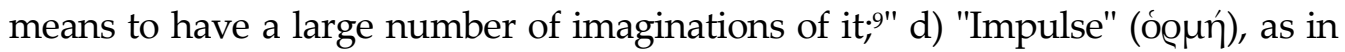
the words of Iamblichus: "The followers of Zeno believe that the soul is divided into eight parts, but that its components are many more: for example, in the hegemonic there are imaginations, assents, impulses and reasoning;"10" e)

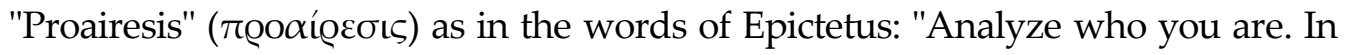
the first place you are a human being, that is a creature who has nothing more dominant than his proairesis and who has the rest subordinated to it, being the proairesis itself neither servant nor subordinate. ${ }^{11 "}$

6. Iamblichus in Stobaeus, "Stoicorum Veterum Fragmenta" (Book I, Fragment 143 (2)).

7. Plutarch, "Stoicorum Veterum Fragmenta" (Book I, Fragment 202).

8. Diogenes Laertius, "Stoicorum Veterum Fragmenta" (Book II, Fragment 837).

9. Aetius, "Stoicorum Veterum Fragmenta" (Book II, Fragment 83).

10. Iamblichus in Stobaeus, "Stoicorum Veterum Fragmenta" (Book II, Fragment 831).

11. Epictetus, "Discourses" (Book II, ch. 10, 1). 


\section{The Synopsis of all the Occurrences of the Term "Hegemonic" in the Works of Epictetus}

For the sake of a greater clarity, it seems appropriate to divide this synopsis of all the occurrences of the term "hegemonic" in Epictetus into three sections. The first section contains all the quotations of the works of Epictetus in which the term "hegemonic" is directly and certainly understood by him to mean "proairesis." This assurance comes from the consideration of the way in which Epictetus, in these fragments, qualifies the hegemonic status, explicitly associating to it at least one of the key features of his own definition of "proairesis:12" a) to operate the diairesis between what is proairetic, that is in our exclusive power, and what is aproairetic, that is not in our exclusive power; $b$ ) to be able to recognize the nature of things and to make the proper use of the imaginations; c) to be able to take an attitude that is in harmony with the nature of things or that is in contrast with it. I shall tag these fragments as $\mathrm{P}$ (Proairesis) followed by a number (P1, P2, etc.) according to the choice explained in Scalenghe ${ }^{13}$ and more analytically in Scalenghe. ${ }^{14}$ The second section contains the quotations of the term "hegemonic" in which there is an explicit reference to

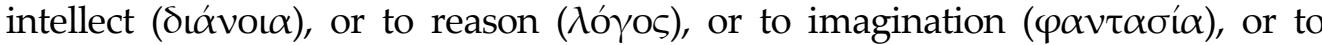
sensation ( $\alpha$ l $\sigma \theta \eta \sigma \iota \varsigma)$, all of which we already know to be involved in the activity of the hegemonic. I shall tag these fragment as HEG (HEGemonic) followed by a number (HEG1, HEG2, etc.). The third section contains the quotations in which the term "hegemonic" has apparently no explicit reference. These fragments are tagged as HEGX1, HEGX2 etc. As I already said, all the present quotations of the works of Epictetus are taken from my new English translation of all Epictetus. ${ }^{15}$

\section{First Section}

Quotations of the term "hegemonic" with the direct meaning "proairesis."

(P1) - "In every circumstance I shall keep my hegemonic in accord with the nature of things."

"Discourses" I,15,4

12. Franco Scalenghe, "Proairesis, Proairetic and Aproairetic: Synopsis of All the Passages Containing these Terms in the "Discourses" and the "Manual" of Epictetus," International Journal of Philosophy 3, no. 3 (2015).

13. Ibid.

14. Franco Scalenghe, "About the Arithmetic and the Geometry of Human Proairesis and the Natural Asymmetry by Which Unhappiness Wins the Game Against Happiness 3 to 1," International Journal of Philosophy 3, no. 6 (2015).

15. William Abbot Oldfather, Epictetus: "The Discourses as reported by Arrian, the Manual and the Fragments." 
(P4) - And all this with courage, relying on the One who called you to do that and judged you worth of this task, appointed to which you will exhibit what a rational hegemonic arrayed against aproairetic forces can do.

"Discourses" II,1,39

(P9) - The subject matter of the virtuous man is his own hegemonic, the body is the subject matter of the physician and of the masseur, the land is the subject matter of the farmer. The work of the virtuous man is the use of the imaginations in accord with the nature of things.

"Discourses" III,3,1

(P10) - Go away; take care of things at home. For if your hegemonic cannot stay here in accord with the nature of things, a bit of land will do the job: you will grow your small coins, you will assist your old father, you will revolve around the market-place, you will hold office. Bad yourself, what will not you badly do of what comes next?

"Discourses" III,5,3

(P11) - Now one has labored to resolve syllogisms, and there are profits. Then, instead, one labored with the aim of keeping our hegemonic in accord with the nature of things, and there were profits.

"Discourses" III,6,3

(P12) - But to what end have the philosophers, then, general principles? To this end: to have our hegemonic in accord with the nature of things and enjoy ourselves, whatever will come about. Do you think this to be a small thing? - No, the greatest.

"Discourses" III,9,11

(P13) - What prevents you, when you have a fever, from having your hegemonic in accord with the nature of things? Here is the control of the business, the evaluation of the one who does philosophy.

"Discourses" III,10,11

(P14) - For it is not the deed of the philosopher to keep these external objects, neither the wine nor the oil nor the body but what? His own hegemonic. And how to manage what is outside? As far as to conduct himself not unreasonably with regard to it.

"Discourses" III,10,16

(P15) - These things do not harmonize. You must be one person only, either good or bad. You must work at your hegemonic or at external objects; to be industrious upon inside things or upon outside things: that is to have the station of a philosopher or of a layman.

"Discourses" III,15,13

(P20) - But if he toils in reference to his own hegemonic, that he may have it and enjoy himself in accord with the nature of things, only then do I call him industrious.

"Discourses" IV,4,43 
(P21) - For "Socrates" very safely remembered that nobody dominates another's hegemonic and wanted nothing else but what was exclusively his own. "Discourses" IV,5,4

(P22) - For this is always the program of the virtuous man. To obtain a praetorship? No; but if this is given to him, to keep his hegemonic, upon this subject matter, in accord with the nature of things.

"Discourses" IV,5,6

(P23) - "Only bend your mind towards these studies at some time," allot some time to your hegemonic. Analyze why you have it and whence it has come, this thing that uses all the rest, that evaluates all the rest, that selects and does not select.

"Discourses" IV,7,40

(P24) - You cannot give full attention to the external objects and to your hegemonic at the same time. If you want those things, give up this one. Otherwise you will have neither one nor the other, being distracted by both.

"Discourses" IV,10,25

(P25) - You must work at your hegemonic or at the external objects; elaborate artfully your inside or things outside; that is to have the position of a philosopher or of a layman.

"Manual" E29,7

(P26) - Precisely as in walking you pay attention not to step on a nail or to twist your foot, so pay attention not to damage your hegemonic.

"Manual" E38

\section{Second Section}

Quotations of the term "hegemonic" with an explicit reference to the terms "intellect" or "reason" or "imagination" or "sensation."

(HEG2) - While over our paltry hegemonic we gape and sleep, accepting heedlessly every imagination: for in this case no penalty befalls us!

"Discourses" I,20,11

(HEG3) - This, then, is the foundation of philosophy: the sensation of how our own hegemonic stands; for after we recognize that it is weak, we will no longer use it for great things.

"Discourses" I,26,15

(HEG5) - The philosophers say that our infirmities too, without doubt, spring up in this way. For when you crave once for money, if a reasoning appraising the evil of this judgement is brought near to your conscience, the craving is stopped and our hegemonic is restored to its original state.

"Discourses" II, 18,8 
(HEG6) - Since remove the fear of death and bring forth as many thunders and lightnings you want. You will recognize how much stillness and fine weather there is in the hegemonic!

"Discourses" II,18,30

(HEG7) - The hegemonic of an insipient fellow is not faithful, it is insecure, it is unscrupulous, it is overcome now by an imagination and now by another one. "Discourses" II,22,25

(HEG8) - For he knew what moves a rational mind and that like the beam of a scale it will incline, whether you want it or not. Show a contradiction to a rational hegemonic and it will divert from it; but if you do not show it, bring charges to yourself rather than to those who do not obey you.

"Discourses" II,26,7

(HEG17) - You must, then, in the first place make your hegemonic pure and this must be your institute of life ...

"Discourses" III,22,19

\section{Third Section}

Quotations of the term "hegemonic" without any precise and explicit reference.

(HEGX1) - Once you have assimilated them show us, instead, some transformation of your hegemonic; as the athletes, as a result of their trainings and eating, show their shoulders; and those who learned some art show the result of what they learned.

"Discourses" III,21,3

(HEGX2) - Paltry hegemonic, the only thing neglected and with no cure! "Discourses" III,22,33

(HEGX3) - But first of all, the hegemonic of the Cynic must be purer than the sun; otherwise, he is necessarily a gambler and one who plays the rogue, because he will reproach other people while he himself is ensnared in some vice.

"Discourses" III,22

Occurrences of the term "hegemonic" in the first section 16

Occurrences of the term "hegemonic" in the second section 7

Occurrences of the term "hegemonic" in the third section 
A Synthetic Summary of the Occurrences of the Terms "Proairesis,"

"Proairetic," "Aproairetic" and "Hegemonic" in the "Stoicorum Veterum Fragmenta" and in the "Meditations" of Marcus Aurelius

The previous synopsis was dedicated to the examination of the texts of Epictetus, but it appears of the highest interest to explore how many are the occurrences of the terms "hegemonic" and "proairesis," "proairetic" and "aproairetic" in two other fundamental Stoic texts.

The first text is the "Stoicorum Veterum Fragmenta," for the analysis of which I took advantage of my new Italian translation of it. ${ }^{16}$ The three books of the SVF deserve to be taken into account, as they are still today the essential key texts for the knowledge of ancient Stoicism. Now, in the Greek fragments of the SVF the term "hegemonic," with the proper meaning of the ruling principle of the soul, appears many times: 10 times in book I; 114 times in book II and 17 times in book III, for a total of 141 times. The striking fact is that in all cases the term "hegemonic" is never used with a direct or indirect reference to "proairesis;" while we have just seen that the fragments with such a reference are the wide majority, up to $62 \%$, in Epictetus. In turn, the terms "proairesis," "proairetic" and "aproairetic" are present in the Greek fragments of the SVF only 18 times, and many of them are quotes taken from Epictetus.

The second fundamental Greek text is represented by the "Meditations" of Marcus Aurelius, for the analysis of which I also took advantage of my new Italian translation of it. ${ }^{17}$ The results of this examination clearly show that in order to indicate the ruling principle of the soul, Marcus systematically prefers the canonic term "hegemonic." He uses it 41 times in his book, while the noun "proairesis" and the adjectives "proairetic" and "aproairetic" are used by Marcus only 8 times [in fragments III,6,1; VI,41,1; VIII,56,1; XI,36,1; XII,3,3; XII,23,5; XII,33,2 (twice)].

\section{The Preference of Epictetus for the Term "Proairesis" With Respect to the Term "Hegemonic"}

A synopsis of all the occurrences of the terms "proairesis," "proairetic" and "aproairetic" in the works of Epictetus has been recently published and is, to my knowledge, the first, complete and the only one available today. ${ }^{18}$ Now, if we consider, as became evident from the prevous synopsis, that Epictetus is not averse to the use of the term "hegemonic," but that he uses it only 26 times in comparison with the 169 times that he employs the terms "proairesis,"

16. Hans von Arnim, "Stoicorum Veterum Fragmenta."

17. Joachim Dalfen, Marci Aurelii Antonini.

18. Scalenghe, Proairesis, Proairetic and Aproairetic. 
"proairetic" and "aproairetic" in his works, ${ }^{19}$ the difference in choice between, on the one hand, Epictetus, and on the other hand, Marcus Aurelius and the many authors of the Greek texts collected in the SVF, turns out to be amazing. This finding becomes even more surprising and clear if we sum it up in the following data: the use of the term "hegemonic" exceeds that of the terms linked to "proairesis" by $783 \%(141 / 18 \times 100)$ in the Greek texts of the SVF, and by $513 \%$ (41/8 x 100) in the "Meditations" of Marcus Aurelius. On the contrary, in the works of Epictetus the use of the terms linked to "proairesis" exceeds that of the term "hegemonic" by $650 \%$ (169/26 x 100). How can this particular choice of Epictetus be explained?

\section{The Human Nature and the Philosophical Problem about "Hegemonic/Proairesis," and "Nature/Nature of Things"}

As we have just seen, out of the Stoic philosophers considered in this paper, Epictetus is the only one who clearly prefers the use of the term "proairesis" in order to define the sovereign and ruling part of the human soul. It seems to me that the most decisive explanation for his choice has not been caught so far and that its essence is deeply philosophical. Let me try to explain why.

After a careful examination of the problem, first of all I must admit that, contrary to the consensus of many academic scholars, the "proairesis" has nothing to do with simple judgments or with life projects, as Aristotle, on the contrary, believes ${ }^{20}$ nor with the so called "free will," nor with cultural models, nor with a choice, an act of choice, a pre-choice or a moral choice, as most of the current literature on the subject mantains. ${ }^{21}$ "Proairesis" is the name that Epictetus gives to our logical faculty when, and only when, it is considered as our only natural faculty that can make the human hegemonic assume a right and virtuous or a wrong and vicious attitude. This happens because the proairesis is the only human faculty able, and specifically dedicated to recognize the

19. Ibid.

20. Franco Scalenghe, Tutto ciò che Aristotele chiama "proairesi" e la "proairesi" di Epitteto sono la stessa cosa? (All that Aristotle calls "proairesis" and "proairesis" Epictetus are the same thing?), article no. 11 at www.epitteto.com, unpublished results.

21. Cesare Cassanmagnago, "Il problema della prohairesis in Epitteto (The problem of Prohairesis in Epictetus)," Rivista di filosofia Neoscolastica LXIX (1977); Robert Dobbin,

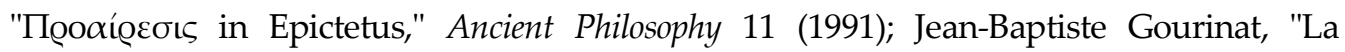
proairesis chez Epictète: decision, volonté, ou personne morale? (Epictetus' proaireis: decision, will, or moral person?)," Philosophie Antique 5 (2005); Rachana Kamtekar, "AI $\Delta \Omega \Sigma$ in Epictetus," Classical Philology 43, no. 2 (1998); Richard Sorabji, "Epictetus on proairesis and Self," in A. Mason A. \& Scaltsas (Eds.), The philosophy of Epictetus (87-98) (Oxford: Oxford University Press, 2007); Rodrigo Sebastiàn Braicovich, "On some rhetorical-pedagogical strategies in Epictetus Discourses concerning proairesis," Eidos 19 (2013). 
"nature of things," that is to establish what is in my exclusive power (the proairetic things: for example, the project of writing what you are now reading) and what is not in my exclusive power (the aproairetic things: for example, the act of actually writing what you are now reading); and then to generate either one or the other of two "superjudgments" that can be called "diairesis" and "counterdiairesis." The proairesis can generate these two "superjudgments" because is naturally endowed with the ability to make a sort of judgmentsquaring, that is some sort of molecular-mathematical operation capable of linking any simple judgment with either the judgment "I care to keep myself in a state of accord with the nature of things" and accordingly make our hegemonic assume the virtuous "diairetic attitude;" or with the judgment "I don't care to keep myself in a state of accord with the nature of things" and in this way make our hegemonic assume the vicious "ounterdiairetic attitude.22" Epictetus gives us a perfect example of what I am saying: "When you are going to undertake a work, remind yourself which is the nature of the work. If you go away for a warm bath, put in front of you the events at the baths: those who sprinkle, those who jostle, those who revile, those who steal." And thus you will undertake the work more safely, if at once you will say: "I dispose to take a warm bath but also to keep my proairesis in accord with the nature of things." And behave in the same way for each work. For thus, if any hindrance to take a warm bath happens, you will have ready at hand that: "Yet I did not dispose only this, but also to keep my proairesis in accord with the nature of things; and I'll not so keep it, if I am vexed at the events. ${ }^{23 "}$ To sum it up and to repeat it more clearly, Epictetus states that human proairesis is a faculty which is: (1) autotheoretical, that is able to evaluate all other human faculties and also itself; ${ }^{24}$ (2) impossible to be subordinated to other human faculties and impossible to be made servant to what is aproairetic; ${ }^{25}$ (3) able to use the imaginations and to understand its own use of them;26 (4) the dominant part of the human hegemonic, that part to which all other human faculties are subordinated and which owns the chain of command that makes us act in a certain way or another in every single circumstance of our life. ${ }^{27}$

This said, I take for granted that for Epictetus the term "hegemonic"

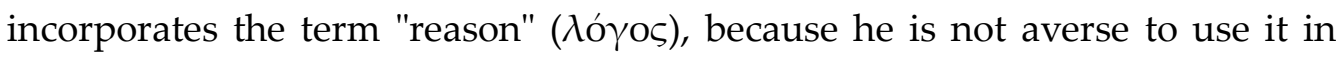
this sense, and because he qualifies "proairesis" as "a logical faculty" already in the first chapter of the first book of his "Discourses." In fact he says: "Among the other arts and faculties you will find none that is able to know its own general principles and therefore none able to self-evaluate positively or

22. Scalenghe, Proairesis, Proairetic and Aproairetic.

23. Epictetus, "Manual" 4.

24. Epictetus, "Discourses" (Book I, ch. 20, 1-6).

25. Epictetus, "Discourses" (Book II, ch. 10, 1).

26. Epictetus, "Discourses" (Book II, ch. 8, 4-8).

27. Epictetus, "Discourses" (Book II, ch. 23, 6-15). 
negatively. To what extent is grammar able to know general principles? To the extent of screening literature. Music? To the extent of screening melody. Does either of them know its own general principles? Not at all. But when, if you write something for a fellow, there is need of the letters that have to be written, these grammar will tell; yet whether one has to write or not for a fellow, grammar will not tell. On melodies also, in the same way, music. It will not say whether one now has to sing and play the lyre or neither sing nor play the lyre. What, then, will? The faculty that knows both its own general principles and all the rest. And what is this? The logical faculty: for this one only has been assumed from nature in order to apprehend itself - what it is, what it can do, how very valuable it has come to be - and all the others. What else says that the gold is wonderful? As the gold does not say so itself, it's plain: it is the faculty able to use the imaginations. What else distinguishes music, grammar, the other arts and faculties; evaluates their uses and points out the right times? Nothing else. ${ }^{28 "}$

It appears however clear that if we interpret these words as an explicit decision of Epictetus to defend the characterization of man as a creature specifically and solely endowed with a "hegemonic," we forget that we are talking here about philosophers for whom the "reason," the $\lambda$ ó $\gamma \mathrm{os}$, permeates not only human beings but all living and non-living creatures and the entire cosmos. In a certain sense, I am confident that the true meaning of the ancient term "hegemonic" is "genomic," and that we can understand it as the old name of what today we know to be written in the double helix of the DNA molecule, that is of the molecule containing all the information indispensable for the life and the reproductive cycle of any living creature. ${ }^{29}$ The preference of Epictetus for the use of the term "proairesis" seems therefore to me highly justified, as soon as we consider that not only the man but any animal is fitted by nature with a "hegemonic." The wonders of which the bees, the wolves, the swallows and all other living creatures, both animals and vegetables, are capable, do not show the presence in them of a hegemonic in some cases less and in some cases even more developed and sophisticated than the human one? It appears to be a highly unsatisfactory answer to maintain that all the other living beings are simply not equipped by nature with the human "reason." This is also generously highlighted by Chrysippus when he says: "Even animals without speech show many basic capacities of their soul, thanks to which they are able to distinguish the foods, to imagine, to avoid the pitfalls, to jump over cliffs and precipices, to recognize many links, I shall not

28. Epictetus, "Discourses" (Book I, ch. 1, 1-6).

29. James Dewey Watson, "La doppia elica (The double helix)" (Milano: Garzanti, 1968); Jeremy Berg, John Tymoczko, Lubert Stryer, "Biochemistry" (New York: W. H. Freeman and Company, 2003). 
say logical but rather natural. ${ }^{30 "}$ Moreover, if we accept the simple definition of virtue and happiness as "life according to nature" and accept the standard conceptions about them as defined by most of the philosophers, both Epicureans and Stoics, we are forced to involve in happiness even minerals. ${ }^{31}$ With regard to this, it is very appropriate to quote here the compelling argument attributed to Michael of Ephesus: "If, as the Stoics say, the good life is to live in accordance with nature; and if to live well, both for the Stoics and for Epicurus, is to be happy, then to live in accordance with nature is to be happy. But it is indeed peculiar of the irrational animals to live in accordance with nature from the moment of their generation to that of their death: therefore nature grants to the animals without hegemonic to be happy. On the other hand if, according to the Stoics, happiness is the supreme of natural desires and we believe that once a natural creature has attained happiness, having its "for what" and its "highest good," it craves nothing more than to keep this good and to never lose it, then this desire exists also in the case of beings devoid of hegemonic and thus also irrational creatures partake of happiness.32" In my opinion, this argument is as simple as deep and unassailable. Has anyone ever seen a tiger, an apple, a piece of granite to act "against nature" and to desire something that is bad or dangerous for them? Evidently not. Therefore it is distinctive of all beings, even those devoid of an hegemonic, to live in a perfect accord with nature and then to be happy.

\section{Conclusion: The Human Nature according to Epictetus}

Here are the words of Epictetus: "You sir [...] are you such as to be able to hear the truth? I would that you were! And yet, since I was somehow condemned to have a hoary beard and a cloak and you enter here like coming to a philosopher, I' 11 use with you neither cruelty nor despair but I' 11 say: younker, whom do you dispose to make beautiful? In the first place recognize who you are and as such adorn yourself. You are a human being: that is a mortal creature able to use the imaginations rationally. What is "rationally?" Acknowledging the nature of things and perfectly. What is, then, special about you? The creature? No. The mortal? No. The use of imaginations? No. The ability to acknowledge the nature of things is the special element that you have: adorn and embellish that. ${ }^{33^{\prime \prime}}$

According to Epictetus, what is then the rightly understood human nature? It is the ability to recognize the nature of things and then to behave in

30. Calcidius, "Stoicorum Veterum Fragmenta."

31. Plotinus, "Enneads" (I, 4).

32. Michael of Ephesus, "Stoicorum Veterum Fragmenta" (Book III, Fragment 17).

33. Epictetus, "Discourses" (Book III, ch. 1, 23-26). 
every situation in a way consistent with it. And which is the nature of things? The nature of things is their essential bipartition in proairetic things and in aproairetic things. And which is the human faculty specifically dedicated to put in place this diairesis and to recognize the difference between what is proairetic and what is aproairetic? It is the proairesis. As can be easily seen, Epictetus is the only philosopher who has been able to define the issue at stake in its exact terms and who has given the correct answer. So the characteristic that distinguishes the man from all other creatures is not the "hegemonic" but the faculty of the hegemonic that he calls "proairesis."

\section{Bibliography}

Aetius. "Stoicorum Veterum Fragmenta." Book II, Fragment 836. "Stoicorum Veterum Fragmenta." Book II, Fragment 83.

Berg, Jeremy, Tymoczko, John, Stryer, Lubert. "Biochemistry." New York: W. H. Freeman and Company, 2003.

Braicovich, Rodrigo Sebastiàn. "On some rhetorical-pedagogical strategies in Epictetus Discourses concerning proairesis." Eidos 19 (2013): 39-56.

Calcidius. "Stoicorum Veterum Fragmenta." Book II, Fragment 879.

Cassanmagnago, Cesare. "Il problema della prohairesis in Epitteto (The problem of Prohairesis in Epictetus)." Rivista di filosofia Neoscolastica LXIX (1977): 232-246.

Dalfen, Joachim. Marci Aurelii Antonini "Ad se ipsum Libri XII" (The Emperor Marcus Aurelius Antoninus "To himself, Books 12"). Leipzig: Teubner, 1979.

Diogenes Laertius. "Stoicorum Veterum Fragmenta." Book II, Fragment 837.

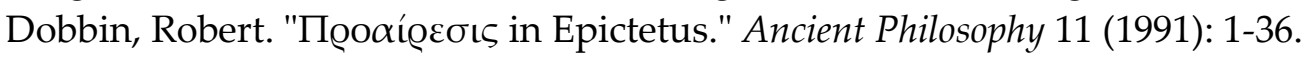

Epictetus. "Discourses." Book I, ch. 1, 1-6.

__. "Discourses." Book I, ch. 20, 1-6.

_.. "Discourses." Book II, ch. 8, 4-8.

_.. "Discourses." Book II, ch. 10, 1.

__. "Discourses." Book II, ch. 23, 6-15.

__. "Discourses." Book III, ch. 1, 23-26.

_.. "Manual" 4.

Gourinat, Jean-Baptiste. "La proairesis chez Epictète: decision, volonté, ou personne morale? (Epictetus' proaireis: decision, will, or moral person?)." Philosophie Antique 5 (2005): 93-133.

Iamblichus in Stobaeus. "Stoicorum Veterum Fragmenta." Book I, Fragment 143 (2). . "Stoicorum Veterum Fragmenta." Book II, Fragment 831.

Kamtekar, Rachana. "AI $\Delta \Omega \Sigma$ in Epictetus." Classical Philology 43, no. 2 (1998): 136-160.

Michael of Ephesus. "Stoicorum Veterum Fragmenta." Book III, Fragment 17. 
Oldfather, William Abbot. Epictetus: "The Discourses as reported by Arrian, the Manual and the Fragments." London: Heinemann, 1961.

Plotinus. "Enneads." I, 4.

Plutarch. "Stoicorum Veterum Fragmenta." Book I, Fragment 202.

Scalenghe, Franco. "Proairesis, Proairetic and Aproairetic: Synopsis of All the Passages Containing these Terms in the "Discourses" and the "Manual" of Epictetus." International Journal of Philosophy 3, no. 3 (2015): 24-33.

"About the Arithmetic and the Geometry of Human Proairesis and the Natural Asymmetry by Which Unhappiness Wins the Game Against Happiness 3 to 1." International Journal of Philosophy 3, no. 6 (2015): 72-82.

__. Tutto ciò che Aristotele chiama "proairesi" e la "proairesi" di Epitteto sono la stessa cosa? (All that Aristotle calls "proairesis" and "proairesis" Epictetus are the same thing?). Article no. 11 at www.epitteto.com. Unpublished results.

Sorabji, Richard. "Epictetus on proairesis and Self." In A. Mason A. \& Scaltsas (Eds.), The philosophy of Epictetus (87-98). Oxford: Oxford University Press, 2007.

von Arnim, Hans. "Stoicorum Veterum Fragmenta" (Ancient Stoic Fragments). Leipzig: Teubner, 1905.

Watson, James Dewey. "La doppia elica (The double helix)." Milano: Garzanti, 1968. 